\title{
Diversifying diversity Library services for underrepresented groups
}

D

iversity and multiculturalism in U.S. colleges and universities has become an important goal over the past 40 years for many reasons: changing demographics, recognition that diverse points of view and ways of thinking enrich the educational experience, and the use of higher education to further social justice and socioeconomic equality. In response, diversity and multiculturalism have become central themes in the mission statements, strategic plans, and goals/priorities of most U.S. institutions of higher education.

Academic libraries have followed the lead of their parent institutions by including diversity in strategic plans, actively recruiting a more diverse workforce and building collections supporting diversity efforts. Despite these efforts, the question remains: Are academic libraries doing enough to further these goals?

In the recent book Multiculturalism on Campus: Theory, Models, and Practices for Understanding Diversity and Creating Inclusion, the authors suggest that creating an inclusive, diverse, and multiculturally competent climate on college and university campuses is the responsibility of the whole institution. The entire campus community "should become involved in creating an environment that has diversity initiatives as its central mission." ${ }^{1}$ In striving to add to these initiatives, many academic libraries have taken the lead from their parent institutions and have created diversity plans of their own. An environmental scan of diversity efforts at academic libraries will reveal that we do an adequate to good job of supporting "traditionally" underrepresented groups like ethnic and racial minorities. However, academic libraries are only beginning to consider how to support and further the diversity goals of other underrepresented groups like nontraditional-age students; lesbian, gay, bisexual, and transgender (LGBT) students; and disabled students.

The major thrust of Multiculturalism on Campus is that "one's cultural identity is more than ethnicity or race" and that "gender, age, religion, geographic identity, and sexual orientation are equally part of the cultural makeup of a multicultural individual." Academic libraries must also consider these facets of diversity and multiculturalism in our diversity efforts, and the collections and services being offered to the campus community. This essay will discuss three underrepresented groups on college and university campuses highlighted in Multiculturalism on Campus, and offer ideas on how academic libraries can create collections and services to support their needs.

\section{Nontraditional age students}

Historically, the age of college and university students ranged from 18 to 24 years and students 25 years or older were considered nontraditional students. Due to many factors, including a volatile economy and the return of many military personnel from wars

Matthew P. Ciszek is head librarian at Penn StateShenango,e-mail: mpc16@psu.edu

(c) 2012 Matthew P. Ciszek 
in Iraq and Afghanistan, nontraditional students, once forming a minority of college students, make up more than 70 percent of those enrolling at colleges and universities in recent years. ${ }^{3}$ Research has shown that adult learners come to higher education with different expectations and preparation for college level work than traditional students and are often juggling work and family obligations with their studies. Academic libraries can serve this segment of students in the following ways:

- provide expanded library hours, including evening and weekend hours;

- develop instructional sessions and workshops providing additional help with navigating technology and online research;

- partner with campus learning centers and student affairs offices in creating seminars and programming around "getting back into a student mindset";

- purchase and highlight collections on parenting, pregnancy and childbirth, work/ school/life balance, and other like topics; and

- provide "busy activities," such as coloring books and other juvenile materials, for children of parents who need to bring their children to the library due to childcare emergencies.

\section{LGBT students}

The term $L G B T$ is generally accepted as those individuals with a sexual orientation and/or gender identity or expression that differs from the majority and can include lesbians, gay men, bisexuals, transgender persons, those labeling themselves as queer or questioning, and others who associate with this community. Numbers of self-identified LGBT students have increased steadily over the last 20 years on college and university campuses. Subsequently, many institutions have created LGBT resource and support centers and include sexual orientation and gender identity/expression in diversity and nondiscrimination policies. Academic libraries can serve this community in a number of ways, including:
- partnering with LGBT student groups and resource centers in developing new services and collections at the library for this community;

- creating research guides on LGBT topics and making them readily available in top-level pages on the library's Web page;

- developing and acquiring special collections in LGBT and Queer Studies;

- supporting LGBT-related events and displays in the library, especially during the months of June (LGBT Pride) and October (National Coming Out Day); and

- training librarians and library staff on sensitivity and awareness of LGBT issues, including the coming out process, antibullying and anti-discrimination policies, and creating safe spaces on campus

\section{Disabled students}

The Americans with Disabilities Act (ADA), passed by Congress in 1990, ensured that people with disabilities were provided the same protections from discrimination as those based on race, ethnicity, creed, gender, or age. As a result, colleges and universities have seen increasing numbers of disabled students, and a 2006 study revealed that over 11 percent of all students at institutions of higher education report a disability. ${ }^{4}$

While great strides have been made by colleges and universities to provide accommodation to students with physical disabilities, additional steps are now being taken to deliver services and support for students with vision and hearing impairments and learning disabilities. Some ways that academic libraries can accommodate this diverse group include:

- providing accessible spaces to those with physical disabilities including variable height service desks and workstations and furnishings;

- ensuring that electronic book collections, online databases, and library Web pages are accessible to those with visual impairments;

- partnering with the campus disabilities office to identify the library and information 
needs of disabled students and develop collections and services to meet these needs;

- purchasing audiobooks, closed captioned video materials, and other alternative media and technology to supplement traditional library collections; and

- additional training for reference staff in assisting with library research and instruction to those students with learning disabilities.

These three groups form only a small segment of the diverse groups of students at a college or university campus in the 21st century. As academic libraries seek to meet diversity goals, we must look beyond the "traditional" facets of diversity and strive to meet the needs of a diversifying population. It is only through this process of "diversifying diversity" will we truly meet the needs of all students.

\section{Notes}

1. Michael J. Cuyjet, Mary F. Howard-Hamilton, and Diane L. Cooper, eds., Multiculturalism on Campus: Theory, Models, and Practices for Understanding Diversity and Creating Inclusion (Sterling, VA: Stylus Publishing, LLC, 2011), 13.

2. Ibid., 2.

3. Susan M. Headden, "'Adult-ed' Grows Up: Higher Education Seeks to Better Serve Increasing Numbers of Nontraditional Learners", Lumina Foundation Focus, Fall 2009, www.luminafoundation.org/wp-content /uploads/2011/02/Focus_Fall_2009.pdf.

4. Laura Horn and Stephanie Nevill, Profile of Undergraduates in U.S. Postsecondary Education Institutions: 2003-04 (Washington, DC: National Center for Education Statistics, 2006), http://nces.ed.gov/pubs2006/2006184_rev. pdf. $n$
("Google Spreadsheets...," cont. from page 530)

of ease with technology to begin with. I've been fortunate to find that many of these students will go out of their way to set up one-on-one research sessions. However, I would still like to help them feel accomplished in their research as we move through the session.

In response, I may have a few paper versions of the spreadsheet available. I can pass this out to any student who gets lost.

Another challenge that I've found is the same with every librarian regardless of the class format, and that's over tasking the session. In fact, my first spreadsheets just had an enormous amount of high-level tasks to complete. Based on what I watched on the spreadsheets, these sessions required a lot more instruction and less hands-on activities, which is exactly the opposite of what I wanted.

While I still fill them with lots of tasks, I try to make sure that they're incremental and result in more practice of skills and critical thinking. As a result, they seem to make better mistakes and more intelligent entries when we move through the class at a one-step-ata-time kind of pace.

\section{Conclusion}

If you are at all like me and also had that same nagging feeling that you could help students more if you could only see and assess what they were doing while in your classroom, then I recommend jumping right into using the spreadsheet.

With so much transparency you will have a hard time returning to previous forms of assessment. I created a sort of Best Practice how-to list in nothing less than a Google Docs. ${ }^{2}$ It explains in lay terms how to create one of these for the first time, regardless of experience with Google Docs in the past. Good luck!

\section{Notes}

1. "Using Google Docs in the Classroom." 2012. In Scoop.It! edited by Gerald Carey,http:// www.scoop.it/t/using-google-docs-in -the-classroom.

2. You can access the "10 Steps to Creating a Google Docs Spreadsheet for Real Time Assessment" at http://tinyurl.com /RealTimeSpreadsheet. Please pay close attention to all of item number 6 when creating one for the first time. $\boldsymbol{n}$ 